\title{
N-Terminal Pro-B-Type Natriuretic Peptide as a Risk Biomarker for Stroke in a General Japanese Population
}

\author{
Hirofumi Tomita
}

Department of Cardiology, Hirosaki University Graduate School of Medicine, Hirosaki, Japan

\section{See article vol. 27: 751-760}

$\mathrm{N}$-terminal pro-B-type natriuretic peptide (NTproBNP) and BNP are mainly secreted from left ventricular myocytes in response to increased wall tension and are well-known biomarkers for heart failure (HF). A recent joint guideline from the Japanese Circulation Society and the Japanese Heart Failure Society states that patients with NT-proBNP level of $\geq 400 \mathrm{pg} / \mathrm{mL}$ or BNP level of $\geq 100 \mathrm{pg} / \mathrm{mL}$ can possibly experience $\mathrm{HF}$, and this likelihood is high in patients with NTproBNP level of $\geq 900 \mathrm{pg} / \mathrm{mL}$ or BNP level of $\geq 200$ $\mathrm{pg} / \mathrm{mL}^{1)}$. Such patients require treatment, and extensive testing or referral to a specialist should be conducted.

Furthermore, plasma NT-proBNP or BNP levels are reported to be associated with stroke risk in patients with atrial fibrillation (AF). The Fushimi AF Registry in Japan demonstrated that patients with high plasma NT-proBNP or BNP levels $(>1,457 \mathrm{pg} /$ $\mathrm{mL}$ or $>169.4 \mathrm{pg} / \mathrm{mL}$, respectively) were at risk for stroke $^{2)}$. Furthermore, the Hokuriku-Plus AF Registry in Japan reported that high plasma BNP levels $(\geq 170$ $\mathrm{pg} / \mathrm{mL}$ ) in patients with non-valvular AF were significantly associated with future thromboembolic events ${ }^{3)}$. In patients with $\mathrm{AF}$ who were treated with oral anticoagulants participating in the Effective aNticoaGulation with factor Xa next GEneration in Atrial Fibrillation-Thrombolysis In Myocardial Infarction study 48 (ENGAGE AF-TIMI 48), high plasma NT-proBNP levels $(\geq 900 \mathrm{pg} / \mathrm{mL})$ were associated with stroke or systemic embolism ${ }^{4}$. These findings indicate that AF patients with high plasma NT-proBNP or BNP levels suggesting the likelihood or high likelihood of HF are at risk for stroke.

In a general Japanese population, the Hisayama study showed that modest plasma NT-proBNP levels $(\geq 125 \mathrm{pg} / \mathrm{mL})$ were associated with ischemic stroke and intracerebral hemorrhage ${ }^{5)}$. Further, the Ohasama study showed that modest plasma NT-proBNP levels $(\geq 125 \mathrm{pg} / \mathrm{mL})$ were significantly associated with an elevated stroke risk with the maximum follow-up period of 5 years ${ }^{6}$. In the present issue of the Journal, Ebihara et al have analyzed data from the Circulatory Risk in Communities Study (CIRCS) and demonstrated that modest plasma NT-proBNP levels $(\geq 125$ $\mathrm{pg} / \mathrm{mL}$ ) were associated with total stroke risk in a general Japanese population ${ }^{7}$. All these findings combined with the above mentioned observations in patients with AF indicate that there is a difference in the plasma NT-proBNP levels suggestive of stroke risk between patients with $\mathrm{AF}$ and a general population, i.e., high plasma NT-proBNP levels in patients with $\mathrm{AF}$, whereas modest levels in a general population. Importantly, Ebihara et al. further showed that high plasma NT-proBNP levels $(\geq 400 \mathrm{pg} / \mathrm{mL})$ were associated with ischemic stroke, especially lacunar and largeartery occlusive stroke, although with a relatively small number of these stroke events ${ }^{7}$. Furthermore, similar results were obtained by the analyses after the exclusion of individuals with AF and those with a history of heart disease or chronic kidney disease (CKD), all of which affect plasma NT-proBNP/BNP levels. These findings are of great interest because elevated NTproBNP levels caused by unknown reasons other than $\mathrm{AF}$, heart disease, and CKD might be associated with a risk for lacunar and large-artery occlusive stroke. As discussed by Ebihara et al, NT-proBNP levels are associated with risk factors for atherosclerotic diseases. Indeed, Matsushita et al. recently reported that NTproBNP levels are independently associated with incident peripheral artery disease by analyzing data from the Atherosclerosis Risk in Communities study ${ }^{8}$. Fur-

Address for correspondence: Hirofumi Tomita, Department of Cardiology, Hirosaki University Graduate School of Medicine, 5 Zaifu-cho, Hirosaki, 036-8562 Japan E-mail: tomitah@hirosaki-u.ac.jp

Received: February 17, $2020 \quad$ Accepted for publication: February 19, 2020

Copyright@2020 Japan Atherosclerosis Society

This article is distributed under the terms of the latest version of CC BY-NC-SA defined by the Creative Commons Attribution License. 
ther studies are required to elucidate the underlying mechanism of this association of plasma NT-proBNP levels with lacunar and large-artery occlusive stroke risk.

Ebihara et al. provides epidemiologically useful and noteworthy information regarding risk management for future stroke incidence in a general Japanese population ${ }^{7)}$. The CIRCS investigators recently reported that elevated serum uric acid levels are an independent predictor of total stroke in women but not in men ${ }^{9}$. Further studies exploring novel risk biomarkers and developing risk management systems for future stroke incidence are highly expected.

\section{Disclosure}

Dr. Hirofumi Tomita received research funding from Bayer, Daiichi-Sankyo, Johnson \& Johnson, and Abbott Medical and Speakers' Bureau/Honorarium from Bayer, Daiichi-Sankyo, and Bristol-Myers Squibb.

\section{References}

1) Tsutsui $H$, Isobe $M$, Ito $H$, Okumura $K$, Ono M, Kitakaze M, Kinugawa K, Kihara Y, Goto Y, Komuro I, Saiki Y, Saito Y, Sakata Y, Sato N, Sawa Y, Shiose A, Shimizu W, Shimokawa H, Seino Y, Node K, Higo T, Hirayama A, Makaya M, Masuyama T, Murohara T, Momomura SI, Yano M, Yamazaki K, Yamamoto K, Yoshikawa T, Yoshimura M, Akiyama M, Anzai T, Ishihara S, Inomata T, Imamura T, Iwasaki YK, Ohtani T, Onishi K, Kasai T, Kato M, Kawai M, Kinugasa Y, Kinugawa S, Kuratani T, Kobayashi S, Tanaka A, Toda K, Noda T, Nochioka K, Hatano M, Hidaka T, Fujino T, Makita S, Yamaguchi O, Ikeda U, Kimura T, Kohsaka S, Kosuge M, Yamagishi M, and Yamashina A: JCS 2017/JHFS 2017 Guideline on Diagnosis and Treatment of Acute and Chronic Heart Failure- Digest Version. Circ J, 2019; 83: 2084-2184

2) Iguchi M, Tezuka Y, Ogawa H, Hamatani Y, Takagi D, An Y, Unoki T, Ishii M, Masunaga N, Esato M, Tsuji H, Wada H, Hasegawa K, Abe M, Lip GYH, and Akao M: Incidence and risk factors of stroke or systemic embolism in patients with atrial fibrillation and heart failure- the
Fushimi AF Registry. Circ J, 2018; 82: 1327-1335

3) Hayashi K, Tsuda T, Nomura A, Fujino N, Nohara A, Sakata K, Konno T, Nakanishi C, Tada H, Nagata Y, Teramoto R, Tanaka Y, Kawashiri MA, and Yamagishi M: Impact of B-type natriuretic peptide level on risk stratification of thromboembolism and death in patients with nonvalvular atrial fibrillation- the Hokuriku-Plus AF Registry. Circ J, 2018; 82: 1271-1278

4) Berg DD, Ruff CT, Jarolim P, Giugliano RP, Nordio F, Lanz HJ, Mercuri MF, Antman EM, Braunwald E, and Morrow DA: Performance of the ABC scores for assessing the risk of stroke or systemic embolism and bleeding in patients with atrial fibrillation in ENGAGE AF-TIMI 48 Circulation, 2019; 139: 760-771

5) Doi Y, Ninomiya T, Hata J, Hirakawa Y, Mukai N, Ikeda F, Fukuhara M, Iwase M, and Kiyohara Y: N-terminal pro-brain natriuretic peptide and risk of cardiovascular events in a Japanese community: the Hisayama Study. Arterioscler Thromb Vasc Biol, 2011; 31: 2997-3003

6) Satoh M, Murakami T, Asayama K, Hirose T, Kikuya M, Inoue $\mathrm{R}$, Tsubota-Utsugi M, Murakami K, Matsuda A, Hara A, Obara T, Kawasaki R, Nomura K, Metoki H, Node K, Imai Y, and Ohkubo T: N-terminal pro-B-type natriuretic peptide is not a significant predictor of stroke incidence after 5 years- the Ohasama Study. Circ J, 2018; 82: 2055-2062

7) Ebihara K, Yamagishi K, Umesawa M, Muraki I, Cui R, Imano H, Kubota Y, Hayama-Terada M, Shimizu Y, Ohira T, Sankai T, Okada T, Kitamura A, Kiyama M, and Iso $\mathrm{H}$ : Moderate levels of $\mathrm{N}$-terminal pro-B-type natriuretic peptide is associated with increased risks of total and ischemic strokes among Japanese: the Circulatory Risk in Communities Study. J Atheroscler Thromb, 2020; 27: 751-760

8) Matsushita K, Kwak L, Yang C, Pang Y, Ballew SH, Sang Y, Hoogeveen RC, Jaar BG, Selvin E, Ballantyne CM, Sharrett AR, Folsom AR, Heiss G, Coresh J, and Hirsch AT: High-sensitivity cardiac troponin and natriuretic peptide with risk of lower-extremity peripheral artery disease: the Atherosclerosis Risk in Communities (ARIC) Study. Eur Heart J, 2018; 39: 2412-2419

9) Li J, Muraki I, Imano H, Cui R, Yamagishi K, Umesawa M, Hayama-Terada M, Ohira T, Kiyama M, Okada T, Sankai T, Tanigawa T, Kitamura A, and Iso H: Serum uric acid and risk of stroke and its types: the Circulatory Risk in Communities Study (CIRCS). Hypertens Res, 2020; 43: $313-321$ 